\title{
PERSPEKTIF MAHASISWA TERHADAP PERKULIAHAN PENDIDIKAN JASMANI DI IAIN SALATIGA
}

\author{
Amanda Syukriadi ${ }^{1}$, Fatkhur Rozi ${ }^{2}$ \\ Universitas Syiah Kuala ${ }^{1}$ \\ IAIN Salatiga ${ }^{2}$ \\ amanda.syukriadi@unsyiah.ac.id ${ }^{1}$,
}

\begin{abstract}
ABSTRAK
Tujuan penelitian ini adalah untuk mengetahui perspektif mahasiswa terhadap perkuliahan pendidikan jasmani di IAIN Salatiga. Penelitian dilakukan dengan survei dengan pendekatan diskriptif kualitatif. Subyek penelitian ini adalah dosen pendidikan jasmani di IAIN Salatiga Tahun 2020. Jumlah responden adalah sebanyak 162 mahasiswa IAIN Salatiga. Hasil penelitian ini adalah mahasiswa menilai kinerja dosen pada lima komponen penilaian, yaitu: tingkat kehadiran, kesiapan, penguasaan materi, penyampaian materi, serta evaluasi dan penilaian perkuliahan. Hasil survei menunjukkan bahwa mahasiswa menilai sangat baik pada rentang $8 \%-34 \%$, kriteria baik sebanyak 54.3\%-58.6\%, kriteria cukup baik sebanyak $14.2 \%-32.1 \%$, kriteria kurang baik sebanyak $0.6 \%-5.6 \%$, dan kriteria tidak baik sebanyak $0-0.6 \%$. Simpulan yang dapat diambil adalah dosen secara umum dinilai baik oleh mahasiswa dalam tingkat kehadiran, kesiapan, penguasaan materi, penyampaian materi, serta evaluasi dan penilaian perkuliahan..
\end{abstract}

Kata Kunci: evaluasi; penilaian mahasiswa; pendidikan jasmani

\begin{abstract}
The purpose of this study was to determine student perspectives on physical education classes at IAIN Salatiga. The study was conducted by a survey with a qualitative descriptive approach. The subjects of this study were physical education lecturers at IAIN Salatiga in 2020. The number of respondents was 162 students of IAIN Salatiga. The results of this study are students assessing the performance of lecturers on five assessment components, namely: the level of attendance, readiness, mastery of the material, the delivery of material, as well as evaluation and evaluation of lectures. The survey results show that students rated excellent in the range of $8 \%$ $-34 \%$, good criteria as much as $54.3 \%-58.6 \%$, criteria enough as many as $14.2 \%-32.1 \%$, criteria of unfavorable as much as $0.6 \%-5.6 \%$, and criteria of not good as much 0-0.6\%. The conclusion that can be drawn is that lecturers are generally valued both by students in their level of attendance, readiness, mastery of the material, delivery of material, and evaluation and assessment of lectures.
\end{abstract}

Keywords: evaluation; student's perspective; physical education

Dipublikasikan Oleh :

UPT Publikasi dan Pengelolaan Jurnal

Universitas Islam Kalimantan Muhammad Arsyad Al-Banjari Banjarmasin 


\section{PENDAHULUAN}

Pendidikan jasmani merupakan salah satu mata pelajaran maupun mata kuliah mulai dari jenjang pendidikan dasar sampai dengan pendidikan tinggi. Pendidikan jasmani (penjas) sendiri merupakan bagian dari ruang lingkup olahraga, yaitu olahraga pendidikan (Rozi \& Setyawati, 2017). Pendidikan jasmani merupakan bagian dari kurikulum pendidikan yang tidak dapat dipisahkan, pendidikan jasmani melekat secara erat pada tujuan pendidikan yang ada. Sebagaimana mengacu pada hakikat pendidikan jasmani, yaitu: bagian integral dari pendidikan secara keseluruhan, bertujuan untuk mengembangkan aspek jasmani melalui aktivitas gerak dan olahraga terpilih yang direncanakan secara sistematis dalam rangka mencapai tujuan pendidikan nasional (Rozi, Azis Purnomo Shidiq, \& Rahman, 2021).

Dewasa ini salah satu tujuan pendidikan nasional adalah tercapainya karakter yang baik bagi generasi penerus Bangsa Indonesia. Karakter ini dapat dihasilkan dari proses pendidikan karakter yang terintegrasi dengan seluruh mata pelajaran maupun mata kuliah. Pendidikan jasmani dapat berperan serta dalam pendidikan karakter, salah satunya adalah jiwa sportivitas (Yuliawan, 2016). Nilai-nilai karakter baik yang ada pada kegiatan pendidikan jasmani (penjas) dan olahraga dapat dicapai selama peserta didik/mahasiswa melakukan kegiatan pembelajaran. Kegiatan bermain dan permainan yang ada pada pembelajaran penjas dapat dijadikan sebagai sarana pendidikan karakter (Utama, 2011). Guru maupun dosen penjas sangat berperan pada ranah ini. Beberapa karakter positif diterapkan oleh pengajar penjas (Mutia, Warni, \& Sarmidi, 2019). Melalui pendidikan karakter inilah, generasi yang bermoral dan berakhlak akan terwujud (Widodo, 2017).

Tujuan penjas lainnya yang khas dibandingkan dengan mata pelajaran/kuliah lainnya adalah perannya dalam membantu peserta didik mencapai derajat kebugaran yang baik (Suherman, 2018). Kebugaran jasmani mengindikasikan kemampuan tubuh dalam beraktivitas harian tanpa mengalami dampak kelelahan yang berarti (Paryanto \& Wati, 2013). Bahkan sampai dengan lansia, faktor kebugaran sangat diperlukan (Kurnianto, 2015). Kebugaran ini dihasilkan selama proses pembelajaran penjas melalui kegiatan aktivitas fisik dan olahraga yang terukur dan tersistem dengan baik.

Tujuan-tujuan penjas di atas tidak dapat tercapai dengan maksimal apabila kompetensi pengajar penjas tidak/kurang kompeten. Pengajar penjas baik itu guru maupun dosen harus memiliki empat kompetensi yang harus dikuasai, yaitu: kompetensi pedagogik, profesional, kepribadian, dan sosial. Kompetensi profesional seringkali belum tercapai secara optimal oleh pengajar penjas, padahal hal ini penting (Raibowo, Nopiyanto, \& Muna, 2019). Sebagai suatu kesatuan, untuk meningkatkan kualitas pembelajaran penjas sudah pasti diperlukan peningkatan kompetensi oleh pengajar penjas. Guna mencapai yang diharapkan tersebut, maka diperlukan pengawasan selama proses pembelajaran penjas (Estrada, Pujianto, \& Arwin, 2019). Selain itu, evaluasi berkala perlu diadakan setiap akhir semester. Hasil evaluasi inilah yang nantinya dapat dijadikan perbaikan.

Pembelajaran praktikum dan teori penjas di IAIN Salatiga mendukung tercapainya tujuan penjas sebagaimana dijelaskan di atas. Selain itu, pengawasan dan evaluasi terhadap dosen penjas dilakukan guna mendukung tercapainya tujuan penjas tersebut. Penelitian ini menjawab bagaimana kompetensi dosen penjas yang ada di IAIN Salatiga berdasarkan penilaian mahasiswa. Sebelumnya telah diadakan penelitian yang sejenis, yaitu evaluasi pembelajaran penjas (Alaswati, 2016). Namun, penelitian tersebut pada tingkat sekolah dan penelitian ini lebih terfokus pada tingkat perguruan tinggi.

Berdasarkan latar belakang dan kajian literatur di atas maka dapat dirumuskan masalahnya sebagai berikut, belum diketahui pelaksanaan pembelajaran penjas dan kompetensi dosen penjas di IAIN Salatiga. Dari perumusan masalah maka tujuan penulisan adalah untuk mengetahui perspektif mahasiswa terhadap perkuliahan pendidikan jasmani di IAIN Salatiga.

\section{METODE}

Penelitian ini adalah penelitian kuantitatif model survei dengan pendekatan deskriptif kuantitatif. Subyek penelitian ini adalah dosen pendidikan jasmani di IAIN Salatiga Tahun 2020. Penelitian dijalankan selama satu semester (6 bulan) pada Tahun Ajaran 2019/2020. Data penelitian ini berupa angket kuisioner dengan jumlah responden sebanyak 162 Mahasiswa. Data yang didapatkan dibuat diagram dan dianalisis dengan cara deskriptif kuantitatif.

\section{HASIL DAN PEMBAHASAN}

Dipublikasikan Oleh : 


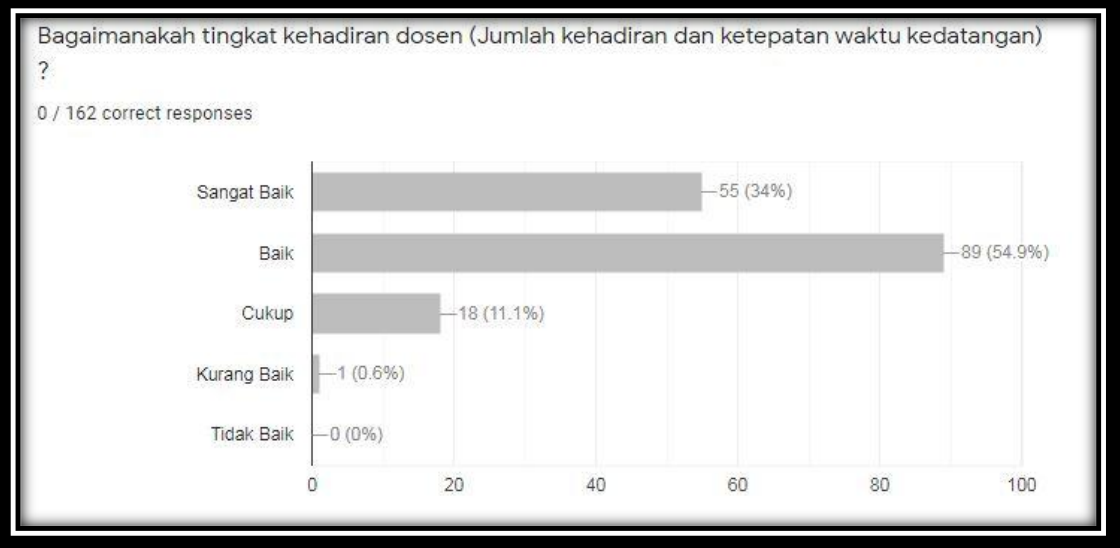

Gambar 1. Hasil Angket Kehadiran Dosen

Gambar di atas menunjukkan penilaian mahasiswa IAIN Salatiga terhadap kehadiran dan ketepatan waktu dosen penjas dalam mengajar. Hasilnya adalah 34\% menilai sangat baik, 54.9\% menilai baik, $11.1 \%$ menilai cukup, dan 0.6\% menilai kurang baik. Berdasarkan data ini, secara umum dosen penjas IAIN Salatiga berada pada penilaian baik dimana $50 \%$ lebih koresponden memberikan penilaian pada kategori tersebut. Selanjutnya, yang masih menjadi catatan adalah adanya penilaian kurang baik dari seorang koresponden $(0.6 \%)$.

Tingkat kehadiran menjadi penting bagi dosen penjas, karena ini merupakan salah satu bentuk penerapan kompetensi kepribadian seorang pengajar penjas. Aspek Kompetisi Kepribadian menunjukkan prilaku yang dapat di teladani dan dicontoh peserta didik (Hermawan, Safei, \& Utama, 2020). Berdasarkan data tersebut, dosen penjas IAIN Salatiga secara umum telah dipandang baik sebagai teladan oleh mahasiswa.

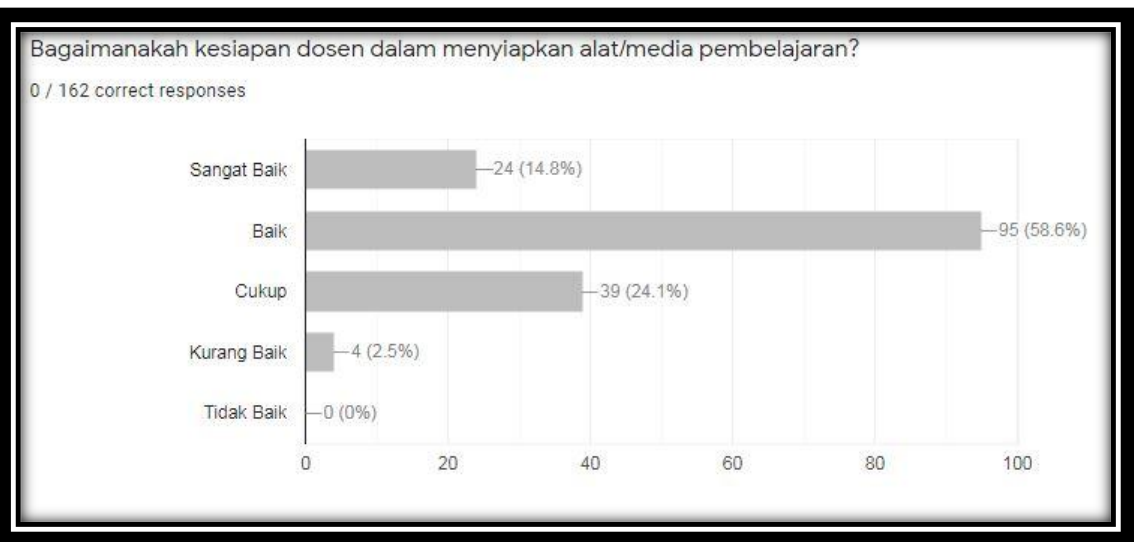

Gambar 2. Hasil Angket Kesiapan Dosen

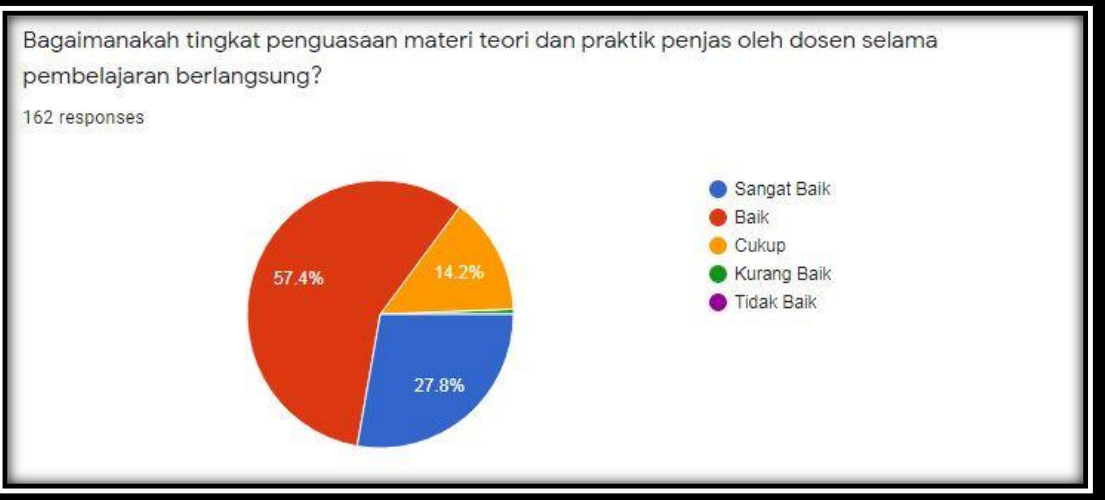

Gambar 3. Hasil Angket Penguasaan Materi Oleh Dosen 
Gambar 2, menunjukkan hasil persepsi mahasiswa IAIN Salatiga terhadap tingkat kesiapan dosen penjas dalam mengajar. Hasilnya adalah $14.8 \%$ menilai sangat baik, $58.6 \%$ menilai baik, $24.1 \%$ menilai cukup, dan $2.5 \%$ menilai kurang baik. Secara umum persepsi mahasiswa terhadap kesiapan dosen penjas dalam mengajar adalah baik. Namun, masih terdapat 4 mahasiswa (2.5\%) yang menilai kurang baik. Kekurangan ini yang hendaknya diperbaiki oleh dosen dikemudian hari agar tidak ada lagi penilaian kurang baik.

Gambar 3, menunjukkan hasil persepsi mahasiswa terhadap penguasaan materi oleh dosen selama mengajar. Hasilnya adalah $27.8 \%$ menilai sangat baik, $57.4 \%$ menilai baik, $14.2 \%$ menilai cukup, dan $0.6 \%$ menilai kurang baik. Secara umum pada aspek ini dosen dinilai baik oleh mahasiswa dalam menguasai materi penjas, meski masih terdapat 1 mahasiswa menilai kurang.

Aspek tingkat kesiapan dan penguasaan materi merupakan salah satu perwujudan kompetensi profesional yang harus dimiliki oleh guru/dosen penjas. Kompetensi profesional merupakan perwujudan penguasaan kompetensi yang luas dan mendalam. Penguasaan materi pembelajaran oleh guru sangat penting guna tercapainya keberhasilan pembelajaran (Sunendang, 2016). Profesionalisme yang tinggi dari dosen sangat dibutuhkan selama pembelajaran penjas di IAIN Salatiga.

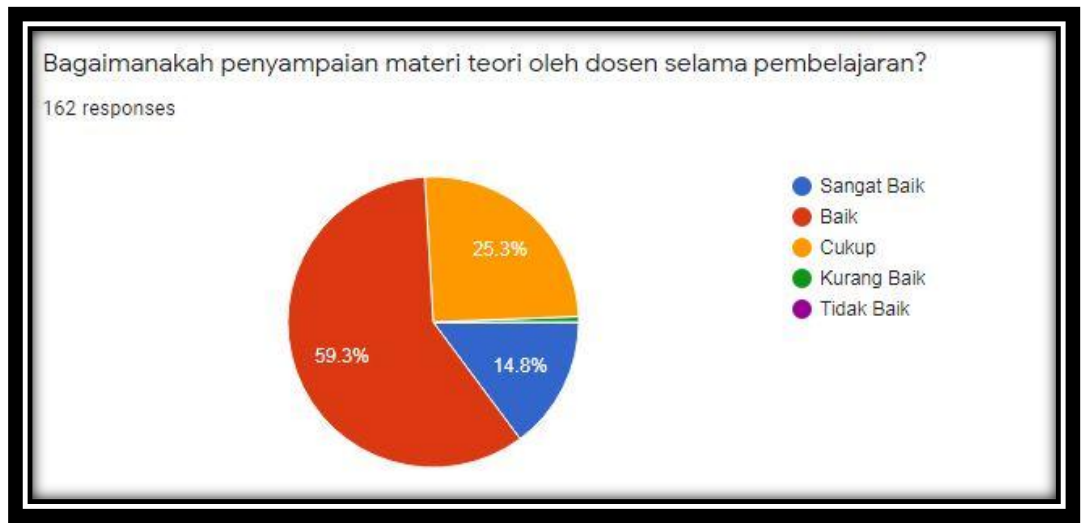

Gambar 4. Hasil Angket Penyampaian Materi Teori Oleh Dosen

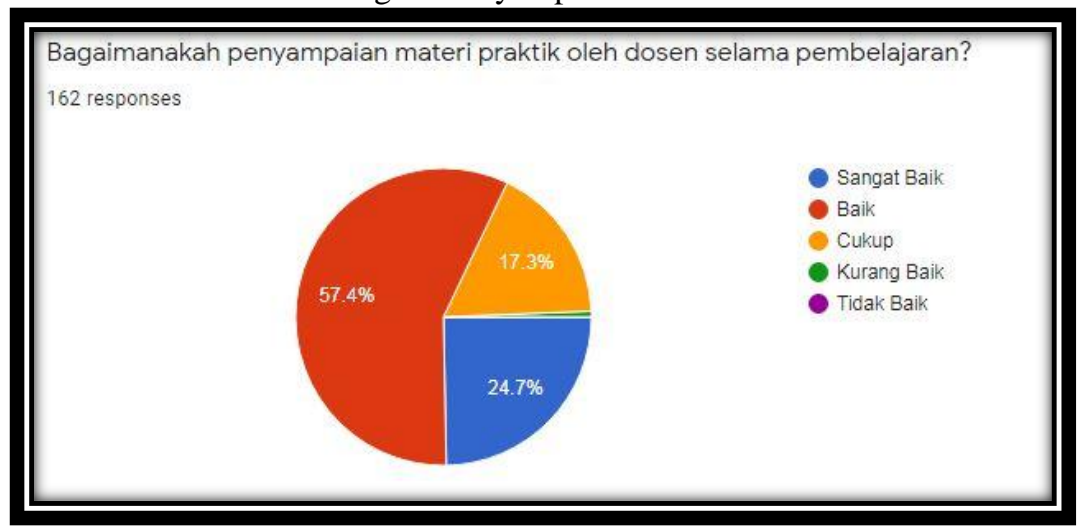

Gambar 5. Hasil Angket Penyampaian Materi Praktik Oleh Dosen

Gambar 4 dan 5, menunjukkan persepsi mahasiswa terkait penyampaian materi oleh dosen selama pembelajaran penjas di IAIN Salatiga. Mahasiswa menilai $14.8 \%$ sangat baik, $59.3 \%$ baik, $25.3 \%$ cukup, dan $0.6 \%$ kurang baik dalam aspek penyampaian materi teori. Sedangkan $24.7 \%$ sangat baik, $57.4 \%$ baik, $17.3 \%$ cukup, dan $0.6 \%$ kurang baik dalam aspek penyampaian materi praktik. Berdasarkan data tersebut, secara umum mahasiswa menilai dosen baik dalam penyampaian materi teori maupun praktik. Adapun hanya satu mahasiswa $(0.6 \%)$ yang menilai kurang baik untuk kedua aspek tersebut.

Aspek penyampaian materi merupakan salah satu bentuk dari penguasaan kompetensi pedagogik. Pedagogik sendiri merupakan kompetensi yang menunjukkan kemampuan guru dalam mengelola pembelajaran, diantaranya pelaksanaan pembelajaran (Fadilah, 2015). Kompetensi pedaggogik nampaknya telah dimiliki dosen penjas secara baik menurut mahasiswa IAIN Salatiga. 


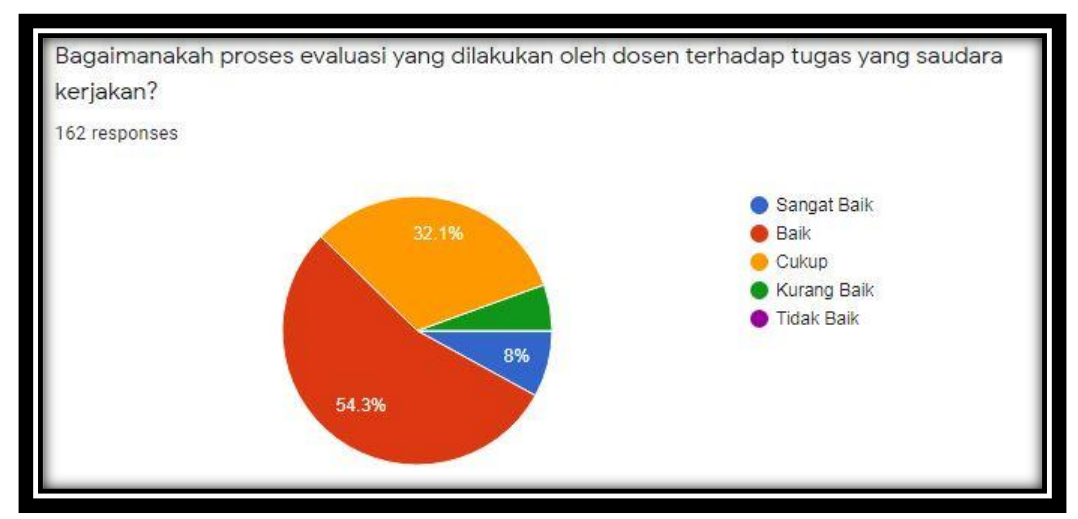

Gambar 6. Hasil Angket Transparansi Dosen

Bagaimanakah ketepatan waktu dosen dalam memberikan nilai terhadap tugas yang saudara kerjakan?

162 responses

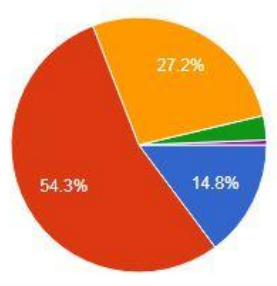

- Sangat Baik

- Baik

Cukup

- Kurang Baik

- Tidak Baik

Gambar 7. Hasil Angket Ketepatan Waktu

Gambar 6 dan 7, menunjukkan persepsi mahasiswa terhadap proses evaluasi hasil belajar dan ketepatan waktu dalam pemberian nilai oleh dosen. Dosen dinilai 8\% sangat baik, $54.3 \%$ baik, 32.1\% cukup, dan $5.6 \%$ kurang baik pada aspek proses evaluasi hasil belajar. Sedangkan untuk aspek ketepatan waktu dalam pemberian nilai adalah $14.8 \%$ sangat baik, $54.3 \%$ baik, $27.2 \%$ cukup serta sisanya kurang baik dan tidak baik. Dosen harus memperhatikan betul aspek ketepatan waktu dalam pemberian nilai karena $2.7 \%$ dinilai kurang/tidak baik.

Kompetensi sosial berkaitan hubungan guru dengan peserta didik, rekan, damasyarakat baik dalam bergaul dan berkomunikasi (Andinta, 2012). Kedua aspek di atas dapat dikatakan sebagai perwujudan kompetensi sosial dosen dalam mengajar penjas dimana berhubungan dengan komunikasi kepada peserta didik (dalam hal ini terkait evaluasi belajar dan pemberian nilai). Tentunya berdasarkan prosentase yang ada, dosen penjas IAIN Salatiga harus meningkatkan kinerjanya secara khusus kepada dua aspek tersebut.

Beberapa aspek yang dikemukakan dapat ditarik hasil secara umum bahwa prosentase pada setiap aspek dinilai pada rentang 8\%-34\% kriteria sangat baik, kriteria baik sebesar 54.3\%-58.6\%, kriteria cukup baik sebesar $14.2 \%-32.1 \%$, kriteria kurang baik sebesar $0.6 \%-5.6 \%$, dan kriteria tidak baik sebesar 0-0.6\%. Namun, kita dapat cermati bahwa secara umum persepsi mahasiswa dalam menilai dosen adalah pada tingkat baik dengan rentang prosentase $54.3 \%-58.6 \%$.

\section{PENUTUP}

Simpulan yang dapat diambil dari penelitian ini adalah dosen penjas IAIN Salatiga dinilai baik oleh mahasiswa dalam tingkat kehadiran, kesiapan, penguasaan materi, penyampaian materi, serta evaluasi dan penilaian perkuliahan. Saran dalam penelitian ini adalah dosen pendidikan jasmani di IAIN Salatiga untuk lebih meningkatkan kinerjanya karena masih didapati penilaian tidak baik, meskipun hanya pada rentang $0-0.6 \%$ (sebanyak satu mahasiswa).

\section{REFERENSI}

Alaswati, Sri. (2016). Evaluasi Pelaksanaan Pembelajaran Kurikulum 2013 PJOK. Journal of Physical Education and Sports, 4(2), 122-128. 
Estrada, Erik, Pujianto, Dian, \& Arwin, Arwin. (2019). Persepsi Kepala Sekolah Terhadap Kinerja Guru Pjok Sekolah Menengah Atas Negeri Di Kota Bngkulu. Kinestetik, 3(2), 198-207. https://doi.org/10.33369/jk.v3i2.8915

Fadilah, Nurul. (2015). KOMPETENSI PEDAGOGIK GURU DALAM PEMBELAJARAN PPKN UNTUK PENCAPAIAN KOMPETENSI SIKAP SPIRITUAL DAN SOSIAL PESERTA DIDIK (Universitas Pendidikan Indonesia). Retrieved from http://repository.upi.edu/17064/5/T_PKN_1302203_Chapter2.pdf

Hermawan, Rahmat, Safei, Imam, \& Utama, Dimas Duta Putra. (2020). STUDI EVALUASI TENTANG KOMPETENSI GURU PENJASORKES SE KABUPATEN LAMPUNG BARAT. Kinestetik: Jurnal Ilmiah Pendidikan Jasmani, 4(1), 90-98. https://doi.org/https://doi.org/10.33369/jk.v4i1.10488

Kurnianto, D. (2015). Menjaga Kesehatan Di Usia Lanjut. Jurnal Olahraga Prestasi, 11(2), 115182. https://doi.org/10.21831/jorpres.v11i2.5725

Mutia, Merliza, Warni, Herita, \& Sarmidi, Sarmidi. (2019). Peran Guru Pendidikan Jasmani Dalam Menanamkan Karakter Keapada Peserta Didik Di Sd Negeri Atu-Atu Kecamatan Pelaihari Kabupaten Tanah Laut. Multilateral Jurnal Pendidikan Jasmani Dan Olahraga, 18(2), 120-125. https://doi.org/10.20527/multilateral.v18i2.7623

Paryanto, Rusadi, \& Wati, Isti Dwi Puspita. (2013). Upaya Meningkatkan Kebugaran Jasmani Siswa Melalui Pendidikan Jasmani. Jurnal Pendidikan Dan Pembelajaran Untan, 2(5), 143-154.

Raibowo, Septian, Nopiyanto, Yahya Eko, \& Muna, Muhammad Khairul. (2019). Pemahaman Guru PJOK Tentang Standar Kompetensi Profesional. Journal Of Sport Education (JOPE), 2(1), 10. https://doi.org/10.31258/jope.2.1.10-15

Rozi, Fatkhur, Azis Purnomo Shidiq, Abdul, \& Rahman, Alvin Yanuar. (2021). ASPEK AMAN, IMUN, DAN IMAN PADA PEMBELAJARAN PENDIDIKAN JASMANI DI IAIN SALATIGA SELAMA PANDEMI COVID-19 [THE ASPECTS OF SAFETY, IMMUNITY, AND FAITH IN PHYSICAL EDUCATION LEARNING AT IAIN SALATIGA DURING THE COVID-19 PANDEMIC]. POLYGLOT: JURNAL ILMIAH, 17(1), 145-158. Retrieved from https://ojs.uph.edu/index.php/PJI/article/view/2908

Rozi, Fatkhur, \& Setyawati, Heny. (2017). Journal of Physical Education and Sports Sosialisasi , Partisipasi, Interaksi Sosial , Gender , dan Norma pada Perkembangan Sepak Takraw Jepara Abstrak. 6(3), 255-260. Retrieved from http://jurnal2.webuir.com/index.php/mydoc8/article/view/376/315

Suherman, Ayi. (2018). Kurikulum Pembelajaran Penjas (Muhammad Nur Alif, Ed.). Sumedang: UPI Sumedang Press.

Sunendang, INDAH HIDAYATY. (2016). PENGARUH KOMPETENSI PROFESIONAL GURU TERHADAP FAKTOR FAKTOR YANG MEMPENGARUHI PRESTASI BELAJAR SISWA (Universitas Pasundan). Retrieved from http://repository.unpas.ac.id/12494/6/BAB II.pdf

Utama, A. M. Bandi. (2011). PEMBENTUKAN KARAKTER ANAK MELALUI AKTIVITAS BERMAINDALAM PENDIDIKAN JASMANI. Jurnal Pendidikan Jasmani Indonesia, 8(1), 1-9. https://doi.org/https://doi.org/10.21831/jpji.v8i1.3477

Widodo, Bintoro. (2017). IMPLEMENTASI NILAI NILAI KARAKTER SISWA PADA PEMBELAJARAN PJOK DI MADRASAH IBTIDAIYAH Bintoro. MADRASAH Jurnal Pendidikan Dan Pembelajaran Dasar, 9(2), 164-168.

Yuliawan, Dhedhy. (2016). PEMBENTUKAN KARAKTER ANAK DENGAN JIWA SPORTIF MELALUI PENDIDIKAN JASMANI OLAHRAGA DAN KESEHATAN. 2(1), 101-112.

Dipublikasikan Oleh :

UPT Publikasi dan Pengelolaan Jurnal

Universitas Islam Kalimantan Muhammad Arsyad Al-Banjari Banjarmasin 